\title{
Online Learning in Civic Education to Increase Understanding of Human Rights Through Ebooks
}

\author{
Royan Abdurrahman ${ }^{1, *}$ Endang Danial ${ }^{2}$ \\ ${ }^{1,2}$ Universitas Pendidikan Indonesia \\ ${ }^{*}$ Corresponding author.Email: royanabdurrahman@upi.edu
}

\begin{abstract}
This research is motivated by the lack of use of media in learning. In the world of education now there have been various advances in the field of technology to support the learning process so that it becomes easier to digest, but along with this progress, it is not directly proportional to the ability of teachers to process technology that has developed so that it causes students to lack understanding of the material. teaching delivered by teachers, this study aims to facilitate students in capturing the contents of the material presented by the teacher, using e-book to be in op e Rasikan through additional applications that can be obtained play store, will make it easier for students to learn and capture human rights material via smartphones, Human rights during the pandemic led to increasing inequality in the economic and social fields, making bad habits and character for students because many violated human rights values such as committing theft and violence ,This research uses the literature study method. The results of this study indicate that (1) students' understanding can increase with the use of ebooks in the learning process, (2) the use of ebooks is more efficient they can be studied anywhere and anytime (3) The use of ebooks that can be opened via smartphones makes it easier for students to learn Independently, the conclusion of this study is that the use of ebooks in the online learning process can be more efficient because it makes it easier for students to enrich the content of the material taught by the teacher, In addition, by utilizing existing technology in learning, students can learn without having to carry a lot of books so that it helps streamline learning time.
\end{abstract}

Keywords: Ebook, Education Technology, Human Rights, Online Learning.

\section{INTRODUCTION}

Education is a set of systems in which there are several indicators to support the learning process, components in education must be holistic so that the goals in education are achieved properly such as indicators of goals, teachers, students, infrastructure, syllabus and assessment. This statement is in accordance with [1] Law Number 20 of 2013 concerning education, learning is a structured effort in carrying out situations in the learning process so that students actively develop their potential and have the toughness of spirituality, self-control, character, knowledge and abilities that must be implemented starting from the formal environment. Non-formal and informal, it can be concluded that learning is a process of growing students' abilities which include not only intelligence but noble character, religious spirituality and intelligence in controlling themselves, then the abilities possessed can be actualized in everyday life. Hierarchically, the goals of education are a stage - the stages that must be passed, especially for students so that the goals of learning can be achieved to the maximum, In order for the implementation of active, creative and fun learning, the components in the education system must have a relationship with each other which includes the achievement of learning objectives, basic competencies, as well as the standard of students' abilities, if there is no holistic harmonization, the objectives in learning are not optimal, because the basic goals have not been met.

To achieve this goal, a learning model and learning tools are needed to support the learning process. During a pandemic, learning is carried out online, so it will be more effective if the learning process is carried out using supporting technologies so that students continue to receive appropriate materials and learning. maximum. [2] Djamarah and Zain (2014) state that each material has varying levels of difficulty. On the one hand, the subject matter does not require tools, but on the other hand, it requires aids such as globes, pictures and so on, especially for students who do not like the subject matter delivered. [3]Suhadi in Aji (2019) stated that learning instruments are media, information and references to support the learning process, learning instruments must be prepared before the learning process begins, Instruments in learning are divided into tools, infrastructure and learning materials. Learning materials are an important part to support learning activities, with this device, materials that are difficult will be simplified so that students do not find 
it difficult to catch the material provided by the teacher, learning tools must be in sync with learning methods and models so that the learning process is in accordance with its objectives during the participant pandemic. students will spend more free time and study at home, the learning materials will be easier to understand, the use of media is a harmonization that is not separated from the world of education, the role of learning media is very important because not all students can capture the contents of learning materials quickly and easily. responsive, teaching materials that are usually delivered in a conventional way and the Teaching Center is less effective when implemented with an online-based home learning system. One of the learning tools used are devices such as Android phones, during the pandemic the learning process has used this Android-based program as a tool to support learning through information devices that use sound, graphics, animation and text. Learning tools already provide what is needed in the learning process such as seeking information, adjusting information and seeking validity in finding information, so that educators can develop materials, learning models that are harmonized with multimedia so that the learning process can be maximized, the use of electronic-based ebooks will it makes it easier for students and teachers in the teaching and learning process because with the ebook students can learn independently without having to bring a book then the learning process can be done anywhere and anytime without having to be bound by classrooms and learning time as usual at school, then there are still many gaps in capabilities teachers in carrying out technology-based learning that has an effect on learning so that in the learning process only give written assignments to students.

Learning applications that are often used and most widely used in the student learning process during online learning, there are various types in their use, some use Google Forms, use visual-based learning such as images, audio-visual-based such as video viewing and use multimedia-based blends. between images, videos and so on like ebooks.

The use of conventional learning during the pandemic is less effective because students are focused only on listening to the material presented by the teacher, it is different with the use of multimedia students can see and hear in the learning process, but it needs serious handling from teachers, students and others to maximize the learning process using ebooks.

Non Thus the learning process carried out with multimedia and supported through appropriate learning methods carried out during the pandami period and studying at home, this statement can be in line with Law no. 20 of 2013 Article 1 which states that noble character, religious spirituality, self-control and personality of students are more important, then after that, the knowledge and skills of students are followed. Material harmonization of the nature and responsibility that is harmonized through multimedia learning E-books that can be accessed on the Android of students in improving and even enriching the understanding of learning outcomes regarding the material.
Therefore, So based on the background that has been stated above, it attracted the attention of the author to study and conduct research on Online learning in civic education to increase understanding of human rights material through ebooks. With the formulation of the problem:

What is the role of ebooks in Online Learning In Civic Education on human rights material as an effort to increase understanding?

\section{METHOD}

The method used is a literature study by examining journals related to the use of multimedia ebooks with a total of 6 pieces, and the number of books related to ebook media with a total of 4 pieces. Literature research does not require researchers to go out into the field to conduct research directly, but use the data needed in research obtained from various documents or other library sources. The results of various literature reviews will be used to theoretically examine the effectiveness of ebooks in improving understanding student.

\section{RESULT AND DISCUSSION}

\subsection{Multimedia Interactive learning in an effort to improve understanding.}

Multimedia is often referred to as a combination of various media or at least consists of more than one media used, according to [4] Warsita (2008) multimedia can be defined as a computer with the ability to process moving images, audio and graphics in high resolution, tools are tools that can be used by For students and teachers to achieve learning objectives [5] Faturrohman, Sutikno, (2010), there are several categories of multimedia programs, one of which is for formal education purposes, besides that multimedia can be interpreted as a combination of various text media, graphics, still images, animation, sound. even videos, electronic books are also the embodiment of guidance between various media so as to create electronic books to convey messages to the public, especially to students in the teaching and learning process.

There are four characteristics of the use of multimedia, namely, optimization of all learning media, interactive, having control over the user and programmed, while active learning multimedia programs have the following advantages:

a) Flexible , in its placement the use of interactive multimedia can be done in the classroom or outside the classroom, in its use it can be done by individuals or by groups, so that in its use it is suitable for everyone.

b) Self-Pacing, serving speed in the learning process, this multimedia can be a stimulant for students to be able to more quickly understand the content of the material presented by the teacher, then for students who still do not understand what is conveyed by multimedia can be given the opportunity to repeat in time grama h longer 
to achieve the maximum results improve the understanding of students in the learning process.

c) Interactive, communication is two-way, which means the program provides opportunities for students to respond.

d) Individual, serving the speed in student learning, multimedia programs are designed to meet the interests and needs of students in increasing understanding in the learning process.

The use of information technology in the learning process begins with Skinner, where the machine does not teach students anything, but the machine is programmed so that it can present material that seems to be interacting with students, this makes an image of education in the current era with the existence of technology. which is increasingly rapid to support the learning process must be accompanied by the capability of the teacher to operate it so that it is appropriate and on target with the learning objectives, in the learning process students' attention to the material is forced and required to always understand whatever the conditions are, because that makes students not understand the material. teaching given by the teacher, Djamarah, Zain (2014).

\subsection{Flexibility of using multimedia}

As a tool in the learning process, according to Gerlach, [6] Aryad, (2002) argues that the device is a bridge between students and teachers, the device can do something that cannot be done by teachers who cannot operate learning media properly, Fixative Characteristics in the device, How to This describes the advantages of devices such as recording, storing, and correcting a symptom that can be reclassified using devices such as audio and video, learning devices can record any events in the past which can then be replayed according to the desired time, Manipulative characteristics in the device is the embodiment of an event or object that needs to be done within a few days, weeks, months and even years, it can be simplified through the editing process which can then be presented in a short time and the Distributive Characteristics in the device is a symptom that is modified through the software. learning process to be given to students which can be linked to the students' personal experiences in accordance with the material being presented, then multimedia has the function of being a learning medium which is to facilitate the learning process, which is as follows :

a) Multimedia is not as an additional function in the learning process, but as a tool to realize effective learning.

b) Media is one of the elements that must be developed by the teacher.

c) In the use of media, the role of the media must be in accordance with the material being developed.

d) The use of media as a complement in the learning process to attract more students attention.

e) The use of media helps students in capturing the content of the material provided by students.

f) With the media, students' learning outcomes can be remembered longer, because they can be studied anywhere and anytime.

The E-book is an interactive learning device in conveying messages because it can provide an audio visual image display, this application has a weakness, namely the lack of students' reading habits using a Smartphone monitor screen so that it makes it easier for students' eyes to experience fatigue. The ebook learning media used can be done anywhere and at any time without being bound by space and time, the use of this ebook media can also be used as a means of independent learning that can be done individually to make it easier for students in the learning process, but the use of this media cannot be done arbitrarily by the teacher because of the lack of understanding in running the multimedia the purpose in the learning process will not be maximized, when the teacher teaches verbally or performs assignments, no matter how the behavior and actions of students, it is a very boring learning and consequently the way in the learning process jar experiences a disadvantage between students and teachers fail to create a creative learning atmosphere to improve students' understanding in learning, each student has different sensory abilities by using a variety of media such as ebooks can provide stimulation to students' senses, the use of media can be interpreted as the use of tools teaching materials such as books, magazines, radio, ebooks, e-modules, films and so on that have advantages and are more efficient and flexible, namely as follows:

a) Helps focus more on the object being studied.

b) Increase students' attention.

c) Can improve understanding, learning outcomes that will encourage students to be independent in learning.

d) Develop a way of thinking.

e) Providing experience in the learning process.

The use of multimedia ebooks is more efficient than using task-based learning because the content of the material is simplified and presented creatively so that students are interested in learning, so variations in the learning process are needed to stimulate student learning (Djamarah \& Zain , 2014) especially learning in an interactive way ,online so that the advantages and advantages of e-books lie in their flexibility so that they can be used anywhere and anytime, have the function of reading them in just a few minutes, then in terms of cost and space, ebooks do not require a bigger place so they are very easy to carry everywhere at a low price. which is more affordable, with ebooks can reduce air pollution in the manufacture of books.

\subsection{Forms Use of multimedia as a means of self-study.}

In the use of ebooks, this device can flip through pages like opening a real book, which can then bring more interesting impressions to students, from each page it can be collaborated with animation features to beautify the appearance of the multimedia e-book [7] Fitryani , (2017). can be used via a smartphone or laptop so that the teaching and learning process can be carried out anywhere and anytime without being bound by space and time which 
encourages students to study independently, with the multimedia being harmonized with human rights materials, with the online teaching and learning process the values of attitudes and values of student tolerance less attention is paid to it, even the wider community has experienced the same thing, the occurrence of crime often occurs due to other factors during the pandemic such as the number of terminations of work contracts, poor businesses and the inability to pay for school, which makes criminal acts increasingly rampant. the meaning of committing theft of motorized vehicles and so on [8] A.ayu \& A. Machfud (2020), according to John Locke, human rights are that every individual is an equal and free being, these natural rights include the right to freedom, the right to own property and the right to life which cannot be disturbed by other individuals [9] Kardiman. (2014), human rights are everything that must be obtained by every individual who is attached to every individual whose existence as a human being, it is appropriate and must be respected, protected, upheld and protected by the nation, [10] Law no. 39 of 1999.

In social life, it cannot be separated from being social and the culture that develops in it, there are two important components that coexist with humans, namely, the social component and the cultural component. be integrity. These indicators are togetherness in mutual cooperation and solidarity for the creation of human rights conditions that are upheld. Fundamentally, cultural understanding is a value that is the result of primordial relationships between humans in the form of ideas and ideas that become human guidelines in behavior and lifestyle, Kardiman (2014 ), this can lead to disintegration within the nation and state and has the potential to trigger human rights problems. Thus this human rights issue will be overcome with the spirit of Bhinneka Tunggal Ika and accommodated differences of opinion in multiculturalism which will give birth to the values of tolerance, openness and mutual respect and at the same time can accelerate fanaticism and egocentrism. Rights will always run parallel to obligations. To create harmonization in social life, humans are aware that in living as a nation and state they will always be faced with choices and actions, because in social life individuals will meet other individuals, individuals with other groups and social groups will meet other social groups, in the freedom of individual beings cannot be said to be absolutely free because this will be limited by the freedom of others, so with this there will be an obligation so that in social life there is always harmony with other individual creatures. Rights and obligations will always go hand in hand because carrying out rights and obligations in life will create an integration between individuals and nationally, obligations can be interpreted as references or guidelines that must be carried out without exception because of an identity attached to each individual (Kardiman, 2014). ), thus the learning process using multimedia ebooks is to encourage students to study independently in an effort to improve understanding of human rights material to solve problems while at the same time providing intelligence, knowledge, skills and attitudes of students in particular so as to foster a sense of responsibility, tolerance and democracy to make student character in everyday life [11] Rejeki, Pagasan.2019).

Table 1. Data on the use of e-modules carried out through applications in the playstore [12] Abdul Haris Rustaman, Muhammad Iqbal, Winda Amelia , (2019).

\begin{tabular}{|l|c|c|}
\hline $\begin{array}{l}\text { Number of } \\
\text { respondents }\end{array}$ & Information & Results \\
\hline $\begin{array}{l}21 \\
\text { respondents }\end{array}$ & $\begin{array}{c}\text { Percentage of } \\
\text { understanding } \\
\text { how to use the } \\
\text { module }\end{array}$ & respondents $66.7 \%$ \\
\hline $\begin{array}{l}\text { The digital } \\
\text { respondents } \\
\text { module has } \\
\text { text, image } \\
\text { and video } \\
\text { descriptions }\end{array}$ & 21 respondents \\
\hline $\begin{array}{l}\text { Digital } \\
\text { respondents }\end{array}$ & $\begin{array}{c}\text { Module helps } \\
\text { in practical } \\
\text { understanding }\end{array}$ & respondents $66.7 \%$ \\
\hline $\begin{array}{l}\text { Understanding } \\
\text { of graphic } \\
\text { techniques } \\
\text { respondents }\end{array}$ & 15 respondents \\
& $\begin{array}{c}\text { after using the } \\
\text { module }\end{array}$ & $71.4 \%$ \\
\hline 21 & $\begin{array}{c}\text { An alternative } \\
\text { to assist in } \\
\text { independent } \\
\text { study and } \\
\text { practicum }\end{array}$ & 19 respondents \\
& \multicolumn{2}{|c|}{$95.2 \%$} \\
\hline
\end{tabular}

Research results (Abdul Haris Rustaman, Muhammad Iqbal, Winda Amelia, 2019). Shows that the use of emodules that can be applied through the playstore of mobile phones in the use of e-modules shows that the average score shows 21 respondents are in medium to high qualifications, this shows that the use of e-modules that can be applied in smartphones can improve understanding.

\section{CONCLUSION}

Based on the results of research and studies that have been carried out in this study, it can be concluded that in online learning that is ongoing until now the use of multimedia such as ebooks has an important role in improving students' understanding in learning because using multimedia can make it easier or simplify material that is considered difficult to become. easier for students to understand, using multimedia can provide opportunities for students who have not been able to listen well and quickly to repeat it again to achieve maximum results, namely increasing student understanding, the use of multimedia is considered more efficient because online learning needs are more suitable and skew-based learning with the use of med i a record should be supported by the ability of teachers in the multimedia proces, if the use is not supported by the multimedia capabilities of the 
teacher, the purpose dida in the learning process will not be achieved, learning becomes boring, students will find it more difficult to understand the content of the material presented by the teacher, it is clear from all these components there must be collaboration to create harmonization

The use of ebooks that can be operated through laptops and even smartphones will encourage students to be able to study independently, in learning the teacher only considers the value of knowledge and skills while the attitude value is only a decoration, this will be a problem of human rights crimes now and in the future. come, and become a joint task of the education tricenter between educators, the environment and families to be the key to the implementation of quality learning.

Civic education is an important component in schools that can make students understand in terms of understanding, skills and attitudes in order to be obedient to the norms that apply in the school, community and family environment, so citizenship education lessons should be accompanied by very varied media so that students always can learn and implement it in their daily lives so that the learning objectives of this civic education can be achieved properly and correctly.

The usefulness of E-learning is in terms of practicality with this method students and teachers not only learn from one direction, students can also learn independently and the benefits of media-based online learning can help students focus on the lessons being studied.

\section{ACKNOWLEDGMENTS}

Praise and gratitude to God Almighty for His power and grace so that this paper can be completed properly, do not forget to greetings to the Prophet Muhammad SAW, to the lecturers who always provide support and guidance to the author, thanks to both people parents and family who always provide support and prayers. Hopefully the support from all parties can provide support for the readers of this paper.

\section{REFERENCES}

[1] Law No. 20 of 2013 concerning learning education.

[2]. Djamarah, Zain. 2014. Strategi Belajar Mengajar Jakarta. Rineka Cipta.

[3] G. Aji. 2019. "Development of Professional 3d Pageflip-Based Learning Media in Islamic Education Subjects Materials for Dressing in Class X at SMAN 1 Banjit, Way Kanan Regency" in a scientific article on Islamic education. Lampung. Raden Intan State Islamic University, Lampung.

[4] B Warsita. 2008. Teknologi Pembelajaran Landasan dan Aplikasinya. Jakarta. Rineka Cipta.

[5] Faturrohman, Sutikno.2010. Strategi Belajar Mengajar Melalui Penanaman Konsep Umum dan Konsep Islami. Bandung. PT Refika Aditama
[6] A . Arsyad . 2002. Media Pembelajaran. Jakarta : PT RajaGrafindo Persada

[7]Fitriyani. 2017. "Learning using 3D Pageflip Professional media and Camtasia Studio 8 media on electrolyte and non-electrolyte solution material in class X Islamic High School AL-Arief Muaro Jambi" in Scientific Articles. Jambi : Jambi University.

[8] A. Ayu \& A. Macfud. The impact of the corona virus pandemic served 19 on the increasing crime of motorcycle theft in Surabaya. Vol.4(3) December 2020.

[9]Kardiman. . 2014. Pancasila and Citizenship Education. Jakarta : Erlangga. PT Gelora Aksara Pratama.

[10] Law no. 39 of 1999 concerning human rights

[11] Rejeki,Pagasan. 2019. "Civic Participation of students and their problems" in the scientific article civicus: Education-research-educational service \& citizenship. Vol 7.(11) Muhammadiyah University of Mataram .

[12]AH Rustaman, $\quad$ M Iqbal, W Amelia . 2019 Development of Digital Computer Graphics Practicum Module 1 in Electronic Publication Format (EPUB) to Improve Understanding of Graphic Engineering Visual Communication Design Students (Topic: Digital Imaging), vol 3 no 1, Trilogy University. (page 44), Singaraja: Ganesha Education University. 